\author{
*. езусько, *. осякін, **. езусько \\ * нститут бот ніки ім.. . . олодного кр їни, \\ вул. ерещенківськ , 2, м. иїв, 01601, кр їн \\ ** ціон льний університет “ иєво- огилянськ к демія” \\ вул. . ковороди, 2, м. иїв, 04070, кр їн
}

перше уз г льнено результ ти п леоклім тичних реконструкцій кількісного рівня, викон них різними метод ми н підст ві м тері лів п лінологічного вивчення відкл дів верхнього плейстоцену рівнинної ч стини кр їни. ведено кількісні пок зники клім ту для рис-вюрмського міжльодовиків'я, дубнівського міжст ді лу т м ксимуму ост ннього зледеніння. роблено висновок про неможливість існув ння первинних рефугіумів теплолюбних т вологолюбних деревних порід н рівнинній території кр їни протягом м ксимуму ост ннього зледеніння (1820 тис. років тому).

лючові слов : п леоклім тичні реконструкції, пізній плейстоцен, рис-вюрмське міжльодовиків'я, дубнівський інтерст ді л.

еред н й кту льніших проблем, які сьогодні турбують людство, передусім треб н зв ти суч сні клім тичні зміни, спричинені як природними, т к і нтропогенними чинник ми. омплексний підхід т міждисциплін рний рівень досліджень з безпечують отрим ння репрезент тивних д них для успішного вирішення цієї скл дної проблеми. ерспективним є ретроспективно-прогностичний спект п леоп лінологічних досліджень, які м ють п леоклім тичне спрямув ння [41]. г льносвітовою тенденцією в обгрунтув нні біостр тигр фічних схем і п леобот нічних реконструкцій плейстоцену т голоцену з вжди було і є вр хув ння п леоклім тичних д них [4].

3 г льнені результ ти п леоклім тичних досліджень відкл дів плейстоцену т голоцену кр їни, викон них у XX т н поч тку XXI ст. свідч ть, що до 80-х років ст. п леоклім тичні реконструкції були викон ні н якісному рівні [2, 3, 22-24, 29, 30]. ротягом ост нніх 30 років п леоклім тичні реконструкції для основних періодів пізнього плейстоцену т голоцену кр їни, звич йно, проводяться н кількісному рівні 3 використ нням різних методик $[6,8-17,19-21,26-28,32-34,37,39,40]$. зн чимо, що в кр їні перші кількісні пок зники клім ту для пізньольодовиків'я т голоцену, які грунтув лися н п лінологічних м тері л х, отрим ні з використ нням інформ ційност тистичного методу . лім нов для території лого олісся [27].

ш мет - цілеспрямов ний н ліз т уз г льнення п леоклім тичних пок зників кількісного рівня, отрим них н підст ві п лінологічних х $\mathrm{p}$ ктеристик відкл дів верхнього плейстоцену рівнинної ч стини кр їни, які опр цьов ні як втор ми, т к і іншими дослідник ми з використ нням різних методів.

порово-пилковий н ліз є головним методом, з допомогою якого отрим но первинний м тері л для под льших реконструкцій кількісних клім тичних пок зників

(2) езусько ., осякін ., езусько ., 2010 
пізнього плейстоцену рівнинної ч стини кр їни. явні сьогодні м тері ли д ли н м змогу обр ти модельними ч совими зріз ми рис-вюрмське (микулинське, мур винське, еемське, перш ф з горохівського викопного грунтового комплексу) міжльодовиків'я, дубнівський (брянський) міжст ді л т м ксимум в лд йського зледеніння (Last Glacial Maximum (LGM)). ля опр цюв ння укр їнського п леоп лінологічного м тері лу використовув ли різні методики п леоклім тичних реконструкцій. прикл д, для обр них н ми ч сових зрізів головними були метод ре логр м т клім тогр м . ричук [18], інформ ційно-ст тистичний метод . лим нов [25] т метод функціон льних типів рослинності ( ) . рентіс [38]. т бл. 1 н ведено список розрізів рівнинної ч стини кр їни, відкл ди яких були п лінологічно сх р ктеризов ні і ст ли основою для проведення п леоклім тичних реконструкцій кількісного рівня для пізнього плейстоцену.

блиця 1

писок досліджених розрізів рівнинної ч стини кр їни

\begin{tabular}{|l|l|l|l|}
\hline озріз & бл сть & н літик & ублік ція \\
\hline \multicolumn{4}{|c|}{ ис-вюрмське міжльдовиків’я } \\
\hline емиходи & иївськ & . еров & {$[21]$} \\
\hline нів & ерк ськ & . еліксон & {$[21]$} \\
\hline олодіїв & в но- p нківськ & . уртов я & {$[14,21]$} \\
\hline иронівк & порізьк & ртюшенко & {$[15]$} \\
\hline \multicolumn{4}{|l|}{ убнівський (брянський) міжст ді л } \\
\hline ояничі & олинськ & . уртов я & {$[19,20]$} \\
\hline зясл в & мельницьк & уртов я & {$[19,20]$} \\
\hline ідберезці & ьвівськ & езусько & {$[7]$} \\
\hline \multicolumn{2}{|l|}{ ксимум ост ннього (в лд йського) зледеніння (Last Glacial Maximum=LGM) } \\
\hline ишлянський р & ернівецьк & оліховськ & {$[10,11]$} \\
\hline орм нь-ІV & ернівецьк & . шкевич & {$[32,40]$} \\
\hline нетівк -II & икол ївськ & р п п & {$[32,40]$} \\
\hline
\end{tabular}

з г льнені результ ти п леоклім тичних досліджень свідч ть, що кількісні пок зники клім ту для рис-вюрмського міжльдовиків'я рівнинної ч стини кр їни отрим ні н підст ві п лінологічних досліджень відкл дів розрізів емиходи, нів, олодіїв т

иронівк з використ нням методів ре логр м т клім тогр м . ричук [15]. зН чимо, що з п леофлористичними м тері л ми викон но п леоклім тичні реконструкції оптимуму рис-вюрмського міжльодовиків'я для території ередк рп ття [14], колишнього дянського оюзу [16] т вропи [15]. т бл. 2 н ведено реконструйов ні клім тичні пок зники для оптимуму рис-вюрмського (микулинського) міжльодовиків'я н території кр їни [15].

езульт ти п лінологічного вивчення відкл дів рис-вюрмського міжльодовиків'я розрізів нів (п лінозони $1,2, \quad 3, \quad 4, \quad 5) \mathrm{T}$ олодіїв (п лінозони $4, \quad 5, \quad 5^{+} \quad 6$, 7, 8) д ють змогу зробити висновок, що суч сний центр концентр ції видів рослин, 3 лишки яких визн чені в відкл д х оптимуму міжльодовиків'я (п лінозони $4, \quad 5$, 6), є, відповідно, в івнічно- хідних льп х т верхів'ях р. льби. уч сний н лог флори фін льних ф з міжльодовиків'я (п лінозони $7, \quad 8$ ) міститься в б сейні р. івнічн він [21]. трим ні д ні свідч ть, що н поч тку міжльодовиків'я (п лінозони 1 , 2) у скл ді рослинного покриву помітну роль відігр в ли ксерофільні т г локсерофільні види рослин і центром суч сної концентр ції більшості видів викопної 
флори є гірські р йони лт ю. той ч с п нув в дост тньо сухий т континент льний клім т, який сприяв уч сті у скл ді рослинного покриву відкритих просторів перигляці льних угрупов нь [21].

блиця 2

еконструйов ні зн чення клім тичних пок зників для оптимуму рисвюрмського (микулинського) міжльодовиків'я н території кр їни

\begin{tabular}{|l|l|l|l|l|l|l|l|}
\hline \multirow{2}{*}{ озріз } & \multicolumn{2}{|l|}{$\begin{array}{l}\text { ідхилення від } \\
\text { суч сних зн чень }\end{array}$} & \multicolumn{2}{l|}{$\begin{array}{l}\text { ічн мплітуд } \\
\text { темпер тур }\end{array}$} & \multicolumn{2}{c|}{ езморозний період } \\
\cline { 2 - 8 } & $\begin{array}{l}\text { оп ди, } \\
\text { мм }\end{array}$ & $\begin{array}{c}1, \\
{ }^{\circ} \mathrm{C}\end{array}$ & $\begin{array}{c}\text { vII, } \\
{ }^{\circ} \mathrm{C}\end{array}$ & $\begin{array}{l}\text { суч сні } \\
\text { зн чення }\end{array}$ & відхилення & $\begin{array}{l}\text { суч сні } \\
\text { зн чення }\end{array}$ & відхилення \\
\hline емиходи & +30 & +5 & -1 & 19 & -6 & 180 & +20 \\
\hline олодіїв & +300 & +3 & +1 & 22 & -2 & 180 & +20 \\
\hline иронівн & +300 & +1 & -2 & 25 & -3 & 200 & +10 \\
\hline
\end{tabular}

результ т ми п лінологічного вивчення відкл дів дубнівського (брянського) міжст ді лу в розріз х олино- оділля отрим но кількісні пок зники клім ту з використ нням ре логічного методу . ричук $[19,20]$ т інформ ційно-ст тистичного методу . лім нов [7]. з г льнені н ми п леоклім тичні пок зники кількісного рівня для одного з середньов лд йських міжст ді лів у дубніський ч с н території олинооділля н ведені в т бл. 3 .

блиця 3

еконструйов ні пок зники клім ту дубнівського (брянського) міжст ді лу для олино- оділля

\begin{tabular}{|c|c|c|c|c|c|}
\hline \multirow[t]{2}{*}{ еріодиз ція } & \multicolumn{4}{|c|}{ леоклім тичні пок зники } & \multirow[t]{2}{*}{ ублік ція } \\
\hline &,${ }^{\circ} \mathrm{C}$ &,${ }^{\circ} \mathrm{C}$ & $\mathrm{v},{ }^{\circ} \mathrm{C}$ & $\begin{array}{l}\text { оп ди, } \\
\text { мм/p }\end{array}$ & \\
\hline інцев $ф$ з міжст ді лу & -2 & $(-15)-(-17)$ & +14 & $350-375$ & \multirow{5}{*}{$\begin{array}{l}\text { ле олісся } \\
\text { [7] }\end{array}$} \\
\hline птим льн ф з & $\begin{array}{l}(+1)- \\
(+2)\end{array}$ & $(-11)-(-12)$ & $+16+17$ & $500-550$ & \\
\hline оч ток міжст ді лу & $(-1)-(-2)$ & $(-14)-(-16)$ & $+14+15$ & $375-400$ & \\
\hline $\begin{array}{l}\text { оч ток голоцену } \\
\text { (=поч ток міжльодови- } \\
\text { ків'я) (преборе л) }\end{array}$ & +4 & $(-9)-(-10)$ & $+16+17$ & 500 & \\
\hline еперішній ч с & +8 & $(-4)-(-5)$ & $+18+19$ & $600-800$ & \\
\hline $\begin{array}{l}\text { оч ткові т кінцеві ф зи } \\
\text { міжст ді лу }\end{array}$ & - & -21 & +14 & 350 & $\begin{array}{l}\text { олинськ } \\
\text { височин } \\
\text { [19] }\end{array}$ \\
\hline еперішній ч с & +7 & $-4,5-5$ & $+17+18$ & $530-620$ & \\
\hline
\end{tabular}

трим ні д ні свідч ть, що н йбільш суттєво від суч сних пок зників клім ту в дубнівський ч с н території олино- оділля відрізнялись середні темпер тури січня т середньорічн кількість оп дів. Зн чимо, що всі кількісні пок зники клім ту (особливо поч ткових т кінцевих ф з міжст ді лу), отрим ні двом різними метод ми, відрізнялись від суч сних. ля відкл дів одного з середньов лд йських міжст ді лів у розрізі ідберезці, які сформув лися в дубнівський ч с, отрим но п лінологічні х р ктеристики поч ткової (термоксеротичн субст дія), оптим льної т кінцевої (термогі- 
гротичн субст дія) ф з [7]. и порівняли кількісні клім тичні пок зники оптимуму дубнівського міжст ді лу т поч тку голоцену (преборе льний ч с) (див. т бл. 3). 'ясов но, що клім тичні умови оптимуму міжст ді лу були суворішими порівняно 3 поч тком голоценового міжльодовиків'я. використ нням методу ре логр м $[19,20]$ визн чено, що суч сним р йоном- н логом дубнівської флори н поч ткових т кінцевих ф з х одного з середньов лд йських міжст ді лів у дубнівський ч с н олинській височині бул флор гірських р йонів івнічного р лу [19], для північної ч стини одільської височини - флор околиць м. мськ [20].

ількісні пок зники клім ту для м ксимуму ост ннього (в лд йського) зледеніння отрим ні двом метод ми - інформ ційно-ст тистичним . лим нов [25] т методом функціон льних типів рослинності . рентіс [38]. держ ні з використ нням методу функціон льних типів рослинності п леоклім тичні пок зники для м ксимуму ост ннього зледеніння рівнинної ч стини пр вобережжя кр їни увійшли до п леоклім тичних реконструкцій для території колишньої івнічної вр зії (ВIOMЕ $18000 \mathrm{BP}$ ) [40]. жливо 3 зн чити, що для цих п леоклім тичних реконструкцій використ но п леоп лінологічні м тері ли, підкріплені р діохронологічними д тув ннями. ля відкл дів м ксимуму ост ннього зледеніння в розрізі орм нь IV отрим но р діовуглецеві д ти $18000 \pm 400(\quad-719)$ т $18560 \pm 2000($-145) [31], для відкл дів розрізу

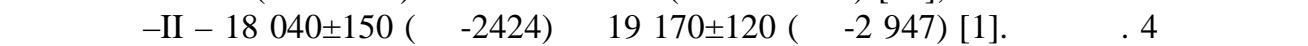
реконструйов ні бсолютні зн чення ( бс.) пок зників клім ту 18000 років тому т відхилення від суч сних пок зників ( ) для рівнинної ч стини кр їни.

блиця 4

еконструйов ні п леоклім тичні пок зники м ксимуму ост ннього зледеніння для рівнинної ч стини кр їни

\begin{tabular}{|c|c|c|c|c|c|c|c|c|c|c|c|c|}
\hline \multirow[t]{2}{*}{ озріз } & \multicolumn{2}{|c|}{${ }^{\circ} \mathrm{C}$} & \multicolumn{2}{|c|}{$\begin{array}{l}\mathrm{V}, \\
{ }^{\circ} \mathrm{C}\end{array}$} & \multicolumn{2}{|c|}{${ }^{\circ} \mathrm{C}$} & \multicolumn{2}{|c|}{$\begin{array}{c}5, \\
{ }^{\circ} \mathrm{C}-д е н ь\end{array}$} & \multicolumn{2}{|c|}{$\begin{array}{l}\alpha, \\
\%\end{array}$} & \multicolumn{2}{|c|}{$\begin{array}{l}\text { п ди, } \\
\text { мм/p }\end{array}$} \\
\hline & бc & & $6 c$ & & бc. & & бc. & & $6 \mathrm{c}$ & & $6 c$ & \\
\hline $\begin{array}{l}\text { нетівк -II } \\
{[32,40]}\end{array}$ & -28 & 28 & 14 & \begin{tabular}{|l|}
-7 \\
\end{tabular} & $\begin{array}{l}-7 \\
\end{array}$ & 17 & 679 & -1678 & 54 & -8 & 193 & -274 \\
\hline $\begin{array}{l}\text { орм нь- V } \\
{[32,40]}\end{array}$ & -29 & 29 & 14 & -6 & -8 & 17 & 566 & -1721 & 57 & -23 & 193 & -397 \\
\hline $\begin{array}{l}\text { ишлянськ } \\
\text { ий p } \\
{[10,11]}\end{array}$ & -25 & - & $14-16$ & - & $(-4)-(-6)$ & - & - & - & - & - & $\begin{array}{c}300- \\
400\end{array}$ & - \\
\hline
\end{tabular}

ількісні пок зники клім ту, отрим ні для 18000 ВР, обгрунтовують суттєві зміни в скл ді рослинного покриву н території кр їни т івнічної вр зії. той ч с суворі клім тичні умови сприяли п нув нню н території рівнинної ч стини кр їни перигляці льного типу рослинності, який поєднув в лісові, степові т тундрові елементи (явище гіперзон льності). ули сформов ні флористичні т ф уністичні комплекси, які не м ють суч сних н логів н території івнічної вр зії. еребудови у скл ді флори т рослинності 18000 років тому відбув лися під впливом змін клім ту глоб льного х p ктеру. ро н йбільшу суворість клім тичних умов у пізньому плейстоцені протягом м ксимуму ост ннього зледеніння свідч ть т кож кількісні пок зники клім ту, отрим ні з п лінологічними м тері л ми . оліховської з використ нням методу . лі- 
м нов для території ереднього одністер'я (розрізи ишлянський p, олодове I, олодове IV) $[10,11]$. ч сі ці п леоклім тичні реконструкції кількісного рівня охопили період від першого р нньов лд йського похолод ння до м ксимуму ост ннього зледеніння. 3 г льнені п леоклім тичні д ні кількісного рівня н ведені в т бл. 5.

блиця 5

еконструйов ні пок зники клім ту пізнього плейстоцену ереднього одністер'я

\begin{tabular}{|c|c|c|c|c|}
\hline \multirow{2}{*}{ еріодиз ція } & \multicolumn{4}{|c|}{ леоклім тичні пок зники } \\
\hline &,${ }^{\circ} \mathrm{C}$ &,${ }^{\circ} \mathrm{C}$ & $\mathrm{v},{ }^{\circ} \mathrm{C}$ & оп ди, мм/p \\
\hline $\begin{array}{l}\text { ксимум ост ннього } \\
\text { зледеніння (18 000- } \\
18560 \text { ВР) }\end{array}$ & $(-4)-(-6)$ & -25 & $(+14)-(+16)$ & $300-400$ \\
\hline $\begin{array}{l}\text { птимум III } \\
\text { середньов лд йського } \\
\text { міжст ді лу }\end{array}$ & $(+4)-(+6)$ & $(-5)-(-6)$ & +20 & $600-800$ \\
\hline $\begin{array}{l}\text { III середньов лд йське } \\
\text { похолод ння }\end{array}$ & $(-1)-(-2)$ & $(-17)-(-19)$ & +15 & $500-600$ \\
\hline $\begin{array}{l}\text { II середньов лд йський } \\
\text { міжст ді л }\end{array}$ & $(+4)-(+5)$ & $(-6)-(-8)$ & $(+18)-(+19)$ & $600-700$ \\
\hline $\begin{array}{l}\text { II середньов лд йське } \\
\text { похолод ння }\end{array}$ & $(-1)-(-2)$ & $(-17)-(-19)$ & +15 & $500-600$ \\
\hline $\begin{array}{l}\text { I середньов лд йський } \\
\text { міжст ді л }\end{array}$ & $(+3)-(+4)$ & $(-8)-(-10)$ & +18 & $600-700$ \\
\hline $\begin{array}{l}\text { I середньов лд йське } \\
\text { похолод ння }\end{array}$ & $(-1)-(-2)$ & $(-17)-(-19)$ & +15 & $500-600$ \\
\hline $\begin{array}{l}\text { III p нньов лд йський } \\
\text { міжст ді л }\end{array}$ & $(+1)-(+2)$ & $(-14)-(-15)$ & $(+16)-(+17)$ & $600-700$ \\
\hline $\begin{array}{l}\text { інцев ф } 3 \text { II } \\
\text { р нньов лд йського } \\
\text { міжст ді лу }\end{array}$ & $0+1$ & -16 & +16 & 600 \\
\hline $\begin{array}{l}\text { птимум II } \\
\text { р нньов лд йського } \\
\text { міжст ді лу }\end{array}$ & $(+1)-(+2)$ & -12 & +18 & $500-600$ \\
\hline $\begin{array}{l}\text { II р нньов лд йське } \\
\text { похолод ння }\end{array}$ & $(-1)-(-2)$ & -19 & +17 & $500-600$ \\
\hline $\begin{array}{l}\text { I р нньов лд йський } \\
\text { міжст ді л }\end{array}$ & $(+1)-(+2)$ & -14 & +18 & $500-600$ \\
\hline $\begin{array}{l}\text { I р нньов лд йське } \\
\text { похолод ння }\end{array}$ & +1 & -16 & +17 & $500-600$ \\
\hline
\end{tabular}

и вв ж ємо, що сьогодні вплив т ких суворих клім тичних умов н розвиток рослинного покриву протягом м ксимуму ост ннього зледеніння перспективно розгляд ти в контексті вирішення т кої скл дної фітогеогр фічної проблеми, як можливість/неможливість існув ння н території кр їни рефугіумів теплолюбних деревних порід. прикл д, з результ т ми н лізу п лінологічних д них ми з'ясув ли, що дуб не бр в уч сті у формув нні рослинного покриву н території рівнинної ч стини кр їни протягом м ксимуму ост ннього зледеніння (18 000-20 000 років тому). тже, отрим ні д ні змогу н м обгрунтув ти неможливість існув ння первинних рефугіумів для 
видів роду Quercus L. протягом м ксимуму ост ннього зледеніння н території кр їни. ей висновок добре узгоджується з результ т ми комплексних п леобот нічних т філогеогр фічних досліджень видів роду Quercus L. флори вропи, з якими протягом м ксимуму ост ннього зледеніння первинні рефугіуми були розт шов ні н територіях берійського, ппенінського т лк нського півостровів $[5,36]$. торинні (пізні, тимч сові) рефугіуми для видів роду Quercus L. т інших теплолюбних і вологолюбних деревних порід н йбільш імовірно існув ли в кр їні протягом пізньольодовикового ч сун 3 ході кр їни ( рп тський регіон т прилеглі території). скл дних процес х формув ння лісів з уч стю широколистяних порід н території кр їни с ме вони відігр в ли провідну роль протягом голоцену [35].

тже, уз г льнені результ ти п леоклім тичних реконструкцій для пізнього плейстоцену т голоцену рівнинної ч стини кр їни свідч ть, що вони відповід ють двом рівням досліджень - якісному (30-80-ті роки $\quad$ ст.) т кількісному (80-ті роки-дотепер).

ля окремих ч сових зрізів пізнього плейстоцену (рис-вюрмське міжльодовиків'я, дубнівський міжст ді л т м ксимум ост ннього зледеніння) н ведені кількісні пок зники клім ту реконструйов ні різними метод ми.

з г льнені результ ти п леоклім тичних реконструкцій кількісного рівня свідч ть, що н йбільш суворими в пізньому плейстоцені були клім тичні умови м ксимуму ост ннього зледеніння, коли були сформов ні флористичні т ф уністичні комплекси, які не м ють суч сних н логів н території кр їни.

трим ні д ні розглянуто в контексті можливості/неможливості існув ння протягом м ксимуму ост ннього зледеніння н рівнинній ч стині кр їні первинних рефугіумів теплолюбної деревної флори. еконструйов ні клім тичні пок зники кількісного рівня унеможливлюють їхне існув ння н дослідженій території. одн с не виключен можливість існув ння вторинних рефугіумів тепло- т вологолюбних деревних порід н території кр їнських рп т (т прилеглих до них регіонів) у пізньольодовиковий ч с.

1. $\quad \begin{aligned} & p \\ & n\end{aligned} . ., \quad m$ нко . ., $m$ ркин . . риродн я сред и р звитие хозяйств позднеп леолитического человек в б ссейне реки жный уг // етвертичный период: методы исследов ния, стр тигр фия и экология. ллинн, 1990. . 31-32.

2. ртюшенко . . стительность есостепи и тепи кр ины в четвертичном периоде (по д нным спорово-пыльцевого н лиз ). иев: ук. думк , 1970. $176 \mathrm{c.}$

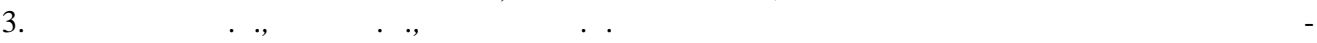
ины в четвертичном периоде. иев: ук. думк , 1982. $136 \mathrm{c}$.

4. езусько .. роблем реконструкції к ртини рослинного покриву кр їни в плейстоцені у пр цях к демік . . еров // ук. 3 п. . риродничі н уки. 2001. .5. .47-50.

5. езусько . ., езусько . ., осякін . ., рем . . ро можливість уч сті дуб у скл ді рослинності рівнинної ч стини кр їни протягом м ксимуму ост ннього зледеніння (з п лінологічними д ними) // ук. з п. . іологія т екологія. 2007. . 67. . 3-9.

6. езусько . ., огуцький . . лінологічн вивченість відкл дів дубнівського викопного грунту олино- оділля. уч сний ст н т перспективи // роблеми стр тигр фії ф нерозою кр їни. б. н ук. пр ць н-ту геол. н ук. ., 2004. . 238-241.

7. езусько .., огуцький . ., лім нов . . ослинність т клім т лого олісся в дубнівському (брянському) міжст ді лі // $\quad$ кр. бот н. журн. 1985. . 42, № 1. . 41-45.

8. езусько .., лим нов . . лім т і рослинність рівнинної ч стини з ходу у пізньопісляльодовиків’я // $\quad$ кр. бот н. журн. 1987. . 43. № $3 . \quad$. 54-58. 
9. езусько . ., лим нов . ., еляг- осонко . . лим тические условия кр ины в позднеледниковье и голоцене // леоклим ты голоцен вропейской территории . ., 1988. $.125-135$.

10. олиховск я . . стительность и клим т реднего риднестровья в позднем плейстоцене. езульт ты п линологического н лиз отложений ишлянского яр // етросы. устьерск я стоянк н реднем нестре. .: ук, 1981. . 103-127.

11. олиховск я . . волюция лессово-почвенной форм ции еверной вр зии. $\quad . \quad$ зд-во оск. ун-т , 1995. $270 \mathrm{c}$.

12. орисов . . лим т позднего дри с внетропической обл сти еверного полуш рия // зв. . 1990. № 4. . .66-74.

13. орисов . . леогеогр фические реконструкции для зоны перигляци льных лесостепей осточной вропы в позднем дри се // ороткопериодные и резкие л ндш фтно-клим тические изменения з последние 15 тыс. лет. . . зд-во , $1994 . \quad .125-149$.

14. орисов . ., уртов я . . лор и р стительность перигляци льной ч сти усской р внины в позднем плейстоцене // леогеогр фическ я основ современных л ндш фтов. езульт ты российско-польских исследов ний. $\quad . \quad$ ук , 1994. . 99-195.

15. еличко . ., ричук . ., уртов я и др. леоклим тические реконструкции для оптимум микулинского межледниковья н территории вропы // зв.

. 15-27.

16. еличко . ., ричук . ., уртов я . ., еликсон . . леоклим т территории в оптимум последнего (микулинского) межледниковья // зв. з . ер. геогр. 1983, № 6. .30-45.

17. ричук . . стительность вропы в позднем плейстоцене // леогеогр фия вропы 3 последние сто тысяч лет. $\quad$. $\quad$ ук , 1982. . . 92-109.

18. ричук . . еконструкция ск лярных клим тических пок з телей по флористичес-ким м тери л м и оценк их точности // етоды реконструкции п леоклим тов. $\quad . \quad$ ук , 1985 . . 20-28.

19. уртов я . . еконструкция природных условий брянского интерв л последней ледниковой эпохи для юго-з п д усской р внины // окл. ․ ер. геогр. 1981. . 257. № 5. . 1225-1228.

20. уртов я . . словия формиров ния дубновского горизонт н северной окр ине одольской возвышенности // линология четвертичного период . . . $\quad . \quad$ ук , $1985 . \quad$. 147-158.

21. уртов я . . зменение клим т в течение микулинского (к 3 нцевского) межледниковья н усской р внине и в ибири // зв. . ер. геогр. 1987. № 2. . 54-62.

22. еров . . олот . ослинність і стр тигр фія..$: \quad$, 1938. 64 с.

23. еров . . рис розвитку рослинності н території кр їнської у четвертинному періоді н основі п леобот нічних досліджень // от н. журн. 1952. . 9. № 4. . .5-19.

24. еров . ., ртюшенко . . стория р стительности кр ины со времени м ксим льного оледенения по д нным спорово-пыльцевого н лиз // етвертичный период. иев:

1961. ып. 13-15. . 300-322.

25. лим нов . . методике восст новления количественных х $\mathrm{p}$ ктеристик клим т прошлого // естн. оск. ун-т . ер. геогр. 1976. № 2. . 92-98.

26. лим нов .. лим т еверной вр зии в позднеледниковье (последний клим тический ритм) // ороткопериодные и резкие л ндш фтно-клим тические изменения 3 последние 15 тыс. лет. .: зд-во , 1994. .61-93.

27. лім нов . ., езусько . . лім т і рослинність лого олісся в голоцені // кр. бот н. журн. 1981. . 38. № 4. . 24-26.

28. ременецкий . . леоэкология древнейших земледельцев и скотоводов усской р внины. $\therefore \quad$ ук , 1991. $193 \mathrm{c}$.

29. шкевич . . еякі д ні про розвиток рослинності н території итомирського олісся під ч с дніпровсько-в лд йського міжльодовикового періоду // кр. бот н. журн. 1962. . 19. № 5. .64-67. 
30. шкевич . . стория ерниговского олесья в поздне- послеледниковое время по д нным спорово-пыльцевого н лиз // роблемы п линологии. иев.: ук. думк , 1971. ып. 1. . 188199.

31. шкевич . . линологическое исследов ние р зрез стоянки орм нь IV // ногослойн я п леолитическ я стоянк орм нь IV..$:$ ук , 1977. . 105-111.

32. $\quad$ сов . . еконструкции клим т и р стительности еверной вр зии позднего плейстоцен по п линологическим д нным // роблемы п леогеогр фии и стр тигр фии плейстоцен . $\therefore$ зд-во оск. ун-т , 2000. . 70-96.

33. ерн вск $я$. ., огель . . зменчивость клим т юго-з п д европейской ч сти голоцене // окл. . 1989. . 307. № 6. . 1474-1477.

34. ерн вск $я$. ., огель . . еконструкция клим т олесья и редк рп тья по п линологическим д нным // зв. . ер. геогр. 1991. № 2. . 98-105.

35. Bezusko L., Mosyakin S., Bezusko A., Mosyakin A. History of formation of the plant cover of the forest zone of Ukraine in the Late Glacial and Holocene (based on palynological evidence) // Man and environment in forest zone: past, present and future. International Conference, July 24-29, 2008, Central Forest State Natural Biosphere Reserve, Russia / Eds.: E.Yu. Novenko, I.I. Spasskaya, A.V. Olchev; Institute of Geography RAS, A.N. Severtsov Institute for Ecology and Evolution RAS. Moscow, 2008. P. 15-16.

36. Brewer S., Cheddadi R., de Beaulieu J. L. et al. The spread of deciduous Quercus throughout Europe since the last glacial period // Forest Ecology and Management. 2002. Vol. 156. P. 27-48.

37. Kremenetski C.V. Holocene vegetation and climate history of southwestern Ukraine // Review of Palaeobotany and Palynology. 1995. Vol. 85. P. 289-301.

38. Prenrice I.C., Quiot J., Huntley B. et al. Reconstructing biomes from palaeoecological data:a general method and its application to European pollen data at 0 and $6000 \mathrm{yr}$ BP // Climate Dynamics. 1996. Vol. 12. P. 185-194.

39. Tarasov P.E., Quiot J., Cheddadi R. et. al. Climate in Northern Eurasia 6000 years ago reconstructed from pollen data // Earth and Planetary Science Letters. 1999, 171. P.635-645.

40. Tarasov P.E., Peyron O., Brewer S., et al. Last Glacial Maximum climate of the former Soviet Union and Mongolia reconstructed from pollen and plant macrofossil data // Climate Dynamics. 1999. Vol. 14. P. 227-240.

41. Seppä H., Bennet K.D. Quaternary pollen analysis: resent progress in palaeoecology and palaeoclimatology // Progress in Physical Geography. 2003. Vol. 27. N 4. P. 548-579.

\title{
PALEOCLIMATIC RECONSTRUCTION FOR THE LATE PLEISTOCENE PERIOD OF THE PLAIN PART OF UKRAINE
}

\author{
*L. Bezusko, *S. Mosyakin, **A. Bezusko \\ *M.G. Kholodny Institute of Botany of the National Academy of Sciences of Ukraine, \\ Tereshchenkivska St., 2, UA-01601 Kyiv, Ukraine \\ ** National Universityof Kyiv-Mohyla Academy, \\ Skovorody St., 2, UA - 04655 Kyiv, Ukraine
}

The article summarizes the results of quantitative paleoclimatic reconstructions conducted using different methods based on the palinological records of the Upper Pleistocene deposits of the plain part of Ukraine. Quantitative climatic characteristics for the Riss-Wurm interglacial period, Dubno interstadial and the Last Glacial Maximum are provided. It is concluded that primary refugia of thermophilic and hydrophilic trees on the plain areas did not exist during the Last Glacial Maximum.

Key words: paleoclimatic reconstructions, Late Pleistocene, Riss-Wurm interglacial period, Dubno interstadial. 


\section{*. езусько * . осякин **. езусько \\ * нститут бот ники им. . . олодного кр ины, \\ ул. ерещзенковск я, 2, м. иев, 01601, кр ин \\ ** цион льный университет “ иево- огилянск я к демия”, \\ ул. . ковороды, 2, г. иев, 04070, кр ин}

первые обобщенно результ ты п леоклим тических реконструкций количественного уровня, проведенных р зличными метод ми н основ нии м тери лов п линологичного изучения отложений верхнего плейстоцен $\mathrm{p}$ внинной ч сти кр ины. риведены количественные пок 3 тели клим т для рисс-вюрмского межледниковья, дубновского интерст ди л и м ксимум последнего оледенения. дел н вывод о невозможности существов ния первичных рефугиумов теплолюбивых и вл голюбивых древесных пород н р внинной территории кр ины в течение м ксимум последнего оледенения (18-20 тыс. лет н 3 д).

лючевые слов : п леоклим тические реконструкции, поздний плейстоцен, рисс-вюрмское межледниковье, дубновский интерст ди л.

т ття н дійшл до редколегії 28.06.2009

рийнят до друку 20.09.2009 